\title{
PENGARUH TERAPI BERMAIN BERCERITA TERHADAP TINGKAT KECEMASAN PADA ANAK USIA PRASEKOLA (3-5 TAHUN) AKIBAT HOSPITALISASI
}

\author{
Renty Fetriani, Dharizal, Agung Riyadi \\ Politeknik Kesehatan Kementerian Kesehatan Bengkulu, Jurusan Keperawatan, \\ Jalan Indragiri Nomor 03 Padang Harapan Bengkulu \\ Email : Fetrianirenty@yahoo.co.id
}

\begin{abstract}
Anxiety is the impact of hospitalization experienced by pre-school children who can disrupt the child's development and healing process. This study aims to determine the influence of play therapy tells the story of anxiety levels of preschoolers who undergo hospitalization. Experimental pre experimental method using a pretestpostest one group design. Sampling technique is accidental sampling with sample of 30 respondents. Paired Test with significance level 95\% $(\alpha<0,05)$. The results showed that the level of anxiety level before the play therapy tells story 28.00 and after the play therapy tells story $21.77, \mathrm{p}$ value $=0.001(<0.05)$ means there is a difference in children before and after doing play storytelling therapy is 6.33 . The conclusion that the play storytelling therapy should be an alternative to decreasing the level of anxiety in children who underwent hospitalization In Dr. Rsud. M.Yunus Bengkulu. It is hoped that other researchers will be able to examine other factors that affect children's anxiety, such as anxiety due to separation, loss, injury, and pain. The research can be done by multiplying the sample being studied and using the comparison group, and the way of random sampling to obtain maximum results
\end{abstract}

Keywords: Hospitalization, Anxiety, Preschool, Play Therapy

\begin{abstract}
Abstrak : Perasaan cemas merupakan dampak dari hospitalisasi yang dialami oleh anak pra sekolah yang dapat mengganggu tumbuh kembang anak dan proses penyembuhan. Penelitian ini bertujuan mengetahui pengaruh terapi bermain bercerita terhadap tingkat kecemasan anak usia prasekolah yang menjalani hospitalisasi. Metode penelitian pra eksperimental dengan menggunakan desain one group pretest-postest. Teknik pengambilan sampel yaitu accidental sampling dengan sample sebanyak 30 responden. Uji Statistik paired t-Test dengan tingkat kemaknaan 95\% $(\alpha<0,05)$. Hasil penelitian menunjukkan bahwa nilai tingkat kecemasan sebelum dilakukan terapi bermain bercerita 28.00 dan setelah dilakukan terapi bermain bercerita 21.77, $\mathrm{p}$ value $=0,001(<0,05)$ artinya ada perbedaan pada anak sebelum dan setelah dilakukan terapi bermain bercerita adalah 6.33. Kesimpulan yaitu terapi bermain bercerita harus menjadi alternatif untuk penurunan tingkat kecemasan pada anak yang menjalani hospitalisasi Di Rsud Dr. M.Yunus Bengkulu. Saran yaitu Diharapkan pada peneliti lain untuk dapat mengkaji faktor lain yang mempengaruhi kecemasan anak, misalnya kecemasan karena perpisahan, kehilangan, perlukaan tubuh, dan rasa nyeri. Penelitiannya dapat dilakukan dengan memperbanyak sampel yang diteliti dan menggunakan kelompok pembanding, dan cara pengambilan sampel secara random sehingga didapatkan hasil yang lebih maksimal.
\end{abstract}

Kata kunci : Hospitalisasi, Kecemasan, Prasekolah, Terapi Bermain

Anak merupakan bagian dari keluarga dan masyarakat. Anak yang sakit dapat menimbulkan suatu stres bagi anak itu sendiri maupun keluarga (Setiawan et al. 2014). Di Amerika Serikat, diperkirakan lebih dari 5 juta anak menjalani atau mengalami hospitalisasi karena prosedur pembedahan dan lebih 
dari $50 \%$ dari jumlah tersebut, anak mengalami kecemasan dan stres. Diperkirakan juga lebih dari 1,6 juta anak usia antara 2-6 tahun menjalani hospitalisasi disebabkan karena injury dan berbagai penyebab lainnya, Disease Control, National Hospital Discharge Survey (NHDS), (Apriliawati, 2011).

Angka kesakitan anak di Indonesia berdasarkan Survei Kesehatan Nasional (SKN) tahun 2010, di daerah perkotaan menurut kelompok usia 0-4 tahun sebesar $25,8 \%$, usia 5-12 tahun sebanyak $14,91 \%$, usia 13-15 tahun sekitar 9,1\%, usia 16-21 tahun sebesar 8,13\%. Angka kesakitan anak usia 0-21 tahun apabila dihitung dari keseluruhan jumlah penduduk adalah $14,44 \%$. Anak yang dirawat di rumah sakit akan berpengaruh pada kondisi fisik dan psikologinya, hal ini disebut dengan hospitalisasi.

Hospitalisasi merupakan salah satu penyebab stress baik pada anak maupun keluarganya, terutama disebabkan oleh perpisahan dengan keluarga, kehilangan kendali, perlukaan tubuh dan rasa nyeri (Nursalam, 2005).

Kecemasan merupakan kekuatan yang besar dalam menggerakkan tingkah laku. Baik tingkah laku normal maupun tingkah laku yang menyimpang, atau yang terganggu, kedua-duanya merupakan pernyataan, penampilan, penjelmaan dari pertahanan terhadap kecemasan (Gunarsa dkk. 2012).

Anak prasekolah adalah anak yang masih dalam usia 3-6 tahun, mereka biasanya sudah mampu mengikuti program prasekolah atau Taman Kanak-kanak. Dalam perkembangan anak prasekolah sudah ada tahapan-tahapanya, anak sudah siap belajar kususnya pada usia sekitar 4-6 tahun memiliki kepekaan menulis dan memiliki kepekaan yang bagus untuk membaca. Perkembangan kognitif anak masa prasekolah berbeda pada tahap praoperasional. Anak prasekolah yang sakit dan harus dirawat di rumah sakit dapat mengalami pengalaman yang tidak menyenangkan. Pengalaman yang tidak menyenangkan pada anak prasekolah memunculkan berbagai respon terhadap pengalaman hospitalisasi. Respon yang paling umum pada anak prasekolah yang menjalani hospitalisasi adalah kecemasan.

Reaksi anak pra sekolah ketika mengalami perawatan di rumah sakit adalah dengan menunjukkan reaksi perilaku seperti protes, putus asa dan regresi. Hal ini bisa dibuktikan dengan anak tampak tidak aktif, sedih, tidak tertarik pada lingkungan, tidak komunikatif, mundur ke perilaku sebelumnya (misalnya: menghisap ibu jari, mengompol dan lain-lain) dan juga perilaku regresi seperti: ketergantungan, menarik diri dan ansietas (Wong, 2003).

Terapi bermain diharapkan mampu menghilangkan batasan, hambatan dalam diri, stres, frustasi serta mempunyai masalah emosi dengan tujuan mengubah tingkah laku anak yang tidak sesuai menjadi tingkah laku yang diharapkan dan anak yang sering diajak bermain akan lebih kooperatif dan mudah diajak kerjasama selama masa perawatan (Mulyaman 2006 dalam Yusuf et al, 2013). Untuk mengurangi kecemasan pada anak yang menjalani hospitalisasi dapat dilakukan diantaranya dengan terapi bermain, relaksasi, terapi musik, aktivitas fisik, dan terapi seni.

Berdasarkan penelitian yang dilakukan oleh Wijayanto (2008), menunjukkan bahwa terapi bermain merupakan terapi yang efektif untuk menghilangan kecemasan anak yang sedang sakit. Karena pada saat dirawat di rumah sakit, anak akan mengalami berbagai perasaan yang sangat tidak menyenangkan seperti cemas, takut, dan sakit. Berdasarkan hal tersebut, dengan melakukan permainan maka akan mengurangi dampak hospitalisasi yang dialami anak, karena dengan melakukan permainan maka anak akan dapat mengalihkan rasa sakitnya pada permainan dan relaksasi melalui kesenangannya 
melakukan permainan. Anak yang sedang dirawat di rumah sakit, perlu diberikan terapi bermain agar anak tidak merasa cemas. Untuk itu perlu diperhatikan jenis permainan yang sesuai dengan situasi dan kondisi yang ada (Wong, 2003).

Melalui cerita, emosi anak selain dapat disalurkan juga dilatih, emosi dapat diajak mengarungi berbagai perasaan manusia. Anak dapat dididik untuk menghayati kesedihan, kemalangan, derita nestapa, anak dapat juga diajak untuk berbagi kegembiraan, kebahagiaan, keberuntungan, dan keceriaan. Melalui cerita perasaan atau emosi dapat dilatih untuk merasakan dan menghayati berbagai peran dalam kehidupan (Sudarmadji et al. 2010).

Dengan bercerita, anak melepaskan ketakutan, kecemasan, mengekspresikan kemarahan dan permusuhan sehingga bercerita adalah media komunikasi antar anak dengan orang lain, termasuk dengan perawat atau petugas kesehatan dirumah sakit.

Hasil pengujian yang dilakukan oleh Putu dkk, dengan Paried t Test yaitu nilai t hitung sebesar 22.306 dan $t$ tabel sebesar 2.045 dengan $\mathrm{p}$ value sebesar 0,000 (< 0,05) Jadi t hitung $>\mathrm{t}$ tabel maka ada uji beda nyata (signifikan) antara sebelum dilakukan terapi bermain menggunakan tehnik bercerita dengan sesudah terapi bermain menggunakan cerita terhadap anak yang sedang dirawat inap, sehingga mendukung hipotesis.

Ada pun data yang diperoleh dari rekam medik RSUD Dr. M. Yunus Bengkulu pada tiga tahun terakhir, jumlah anak yang menjalani perawatan/rawat inap pada tahun 2013 sebanyak 225 orang, pada tahun 2014 sebanyak 325 orang dan pada tahun 2015 sebanyak 461 orang.

Berdasarkan hasil studi pendahuluan yang dilakukan oleh peneliti di Ruang Edelweis RSUD Dr. M. Yunus Bengkulu, jumlah pasien anak dari bulan JanuariDesember sebanyak 525 orang. Pada saat observasi tanggal 24 November 2016 jumlah anak yang dirawat berjumlah 18 orang, 11 orang anak mengalami cemas dengan menunjukkan reaksi menangis ketika dilakukan tindakkan keperawatan seperti pemasangan infus, dan injeksi, anak bersandar pada orang tuanya, dan memalingkan wajah dari perawat. Selain itu juga factor yang membuat anak cemas menurut orang tua anak yakni pakaian putih petugas kesehatan, bau khas obat, dan alat-alat medis kesehatan.

Dari hasil observasi yang dilakukan peneliti terhadap perawat di ruang Edelweis RSUD Dr. M. Yunus Bengkulu, didapatkan hasil bahwa tidak adanya ruang khusus yang digunakan sebagai tempat untuk terapi bermain bagi anak yang menjalani perawatan, selain itu juga belum ada perlakuan atau tindakan keperawatan untuk mengatasi masalah hospitalisasi serta tidak adanya Standart Prosedur Operasional (SPO) terhadap pasien anak yang mengalami dampak hospitalisasi.

\section{BAHAN DAN CARA KERJA}

Jenis penelitian yang digunakan adalah pra eksperimental dengan menggunakan desain one group pretestpostest, kelompok subjek di observasi sebelum dilakukan intervensi, kemudian di observasi lagi setelah intervensi. Tempat penelitian dilakukan di ruang Edelweis RSUD Dr. M. Yunus Bengkulu dan waktu penelitian dilaksanakan pada bulan Januari-Maret 2017, dalam penelitian ini sampel diambil menggunakan accindental sampling dengan sample sebanyak 30 responden. Sampel yang digunakan adalah responden yang memenuhi kriteria inklusi dan eksklusi. Pada penelitian ini yang menjadi kriteria inklusi yaitu anak usia 3-5 tahun, anak dapat diajak komunikasi, anak kooperatif, anak yang di rawat 1-6 hari, anak yang mengalami kecemasan ringan, sedang, dan berat.Kriteria eksklusi pada penelitian ini yaitu, anak mengalami gangguan mental, gangguan tumbuh kembang atau kelainan yang mempengaruhi hasil observasi. anak 
dengan kondisi penurunan kesadaran, dalam penelitian ini penulis menggunakan instrumen penelitian berupa kuesioner
HARS (Hamilton Anxiety Rating Scale) yang sudah dimodifikasi.

\section{HASIL}

\section{Analisis Univariat}

Tabel 1. Distribusi Rata-Rata Tingkat Kecemasan Pada Anak Sebelum dilakukan Terapi Bermain Bercerita Di Instalasi Rawat Inap Ruang Edelweis RSUD Dr. M. Yunus Bengkulu

\begin{tabular}{|c|c|c|c|c|c|c|c|c|}
\hline \multicolumn{3}{|c|}{ Variabel } & $\mathbf{N}$ & Mean & Standar Deviasi & Min & Max & $95 \%$ CI of mean \\
\hline $\begin{array}{l}\text { Kecemasan } \\
\text { dilakukan } \\
\text { bercerita }\end{array}$ & $\begin{array}{c}\text { pada anak } \\
\text { terapi }\end{array}$ & $\begin{array}{l}\text { sebelum } \\
\text { bermain }\end{array}$ & 30 & 28 & 2.959 & 21 & 32 & $26.89-29.11$ \\
\hline
\end{tabular}

Hasil analisis rata-rata tingkat kecemasan pada anak sebelum dilakukan terapi bermain bercerita adalah 28.00 dengan kategori kecemasan berat, standar deviasi 2.959. Nilai kecemasan pada anak sebelum dilakukan terapi bermain terkecil 21 (kecemasan sedang), dan tertinggi 32 (kecemasan berat). Dari hasil estimasi interval dapat disimpulkan bahwa sebelum dilakukan tindakan terapi bermain bercerita adalah diantara 26.89 sampai dengan 29.11 (kategori kecemasan sedang sampai kecemasan berat).

Tabel 2. Distribusi Rata-Rata Tingkat Kecemasan Pada Anak Setelah dilakukan Terapi Bermain Bercerita Di Instalasi Rawat Inap Ruang Edelweis RSUD Dr. M. Yunus

\begin{tabular}{lcccccc}
\hline Variabel & $\mathrm{N}$ & Mean & $\begin{array}{l}\text { Standar } \\
\text { Deviasi }\end{array}$ & Min & Max & $\begin{array}{c}95 \% \\
\text { CI of } \\
\text { mean }\end{array}$ \\
\hline $\begin{array}{l}\text { Kecemas } \\
\text { an pada } \\
\text { anak }\end{array}$ & & & & & & \\
$\begin{array}{l}\text { setelah } \\
\text { dilakuka } \\
\text { n terapi } \\
\text { bermain } \\
\text { bercerita }\end{array}$ & 30 & 21.77 & 4.040 & 13 & 26 & $20.26-$ \\
\hline
\end{tabular}

Hasil analisis rata-rata tingkat kecemasan pada anak setelah dilakukan terapi bermain bercerita adalah 21.77 dengan kategori kecemasan sedang, standar deviasi 4.040. Nilai kecemasan pada anak setelah dilakukan terapi bermain bercerita terkecil 13 (tidak ada kecemasan), dan tertinggi 26 (kecemasan berat). Dari hasil estimasi interval dapat disimpulkan bahwa sebelum dilakukan tindakan terapi bermain bercerita adalah diantara 20.26 sampai dengan 23.28 (kategori kecemasan ringan sampai kecemasan sedang).

\section{Analisis Bivariat}

Analisis bivariat bertujuan untuk mengetahui adanya perbedaan kecemasan sebelum dan sesudah dilakukan terapi bermain bercerita yaitu dengan menguji paired t-test pada alfa 5\%. Untuk melihat kemaknaan, apabila nilai $\mathrm{P}<0,5 \%$ ada perbedaan rata-rata tingkat kecemasan pada anak prasekolah akibat hospitalisasi sebelum diberikan terapi bermain bercerita, sebaliknya jika nilai $\mathrm{P}>0,5 \%$ tidak ada perbedaan rata-rata tingkat kecemasan pada anak prasekolah akibat hospitalisasi sebelum diberikan terapi bermain bercerita.

Tabel 3. Distribusi Rata-Rata Tingkat Kecemasan Pada Anak Sebelum Dan Sesudah Dilakukan Terapi Bermain Bercerita Di Instalasi Rawat Inap Ruang Edelweis RSUD Dr. M. Yunus Bengkulu

\begin{tabular}{lllllll}
\hline $\begin{array}{l}\text { Tingkat } \\
\text { kecemasan }\end{array}$ & $\mathrm{N}$ & $\begin{array}{l}\text { Mean } \\
\text { Median }\end{array}$ & SD & SE & $\begin{array}{l}\mathrm{T} \\
(\mathrm{df})\end{array}$ & $\mathrm{P}$ \\
\hline $\begin{array}{l}\text { Sebelum } \\
\text { intervensi }\end{array}$ & 30 & 28.00 & 2.9 & 540 & 14.3 & 0,001 \\
& 29.00 & 59 & & 85 & \\
Setelah & 30 & 21.77 & 4.0 & 738 & $(29)$ & \\
intervensi & & 23.00 & 40 & & & \\
& & & & & & \\
\hline
\end{tabular}

Rata-rata tingkat kecemasan pada pasien anak sebelum dilakukan terapi bermain bercerita adalah 28.00 dengan kategori kecemasan berat, standar deviasi 
2.959, sedangkan tingkat kecemasan pada anak setelah dilakukan terapi bermain bercerita adalah 21.77 dengan kategori kecemasan sedang, standar deviasi 4.040. Hasil uji statistik menunjukan bahwa nilai $\mathrm{p}$ value $=0,001$, artinya ada perbedaan tingkat kecemasan sebelum dan sesedah terapi bermain bercerita sehingga dapat disimpulkan ada pengaruh terapi bermain bercerita terhadap tingkat kecemasan pada anak usia prasekolah (3-5 tahun) akibat hospitalisasi.

\section{PEMBAHASAN}

\section{Gambaran Kecemasan Pada Anak Usia Prasekolah Sebelum Dilakukan Terapi Bermain}

Sebelum pelaksanaan perlakuan (intervensi) dengan tindakan terapi bermain bercerita untuk melihat pengaruhnya terhadap tingkat kecemasan pada anak dilakukan pengukuran pertama kecemasan terhadap seluruh responden dengan menggunakan "lembar observasi berdasarkan skala HARS yang sudah dimodifikasi".

Hasil penelitian didapatakan nilai rata-rata tingakat kecemasan pada anak sebelum dilakukan tindakan terapi bermain bercerita adalah 28.00 dengan kategori kecemasan berat (95\% CI: 26.89-29.11). Hal ini menunjukan bahwa setiap pasien akan mengalami kecemasan. Dalam penelitian yang dilakukan oleh Wijayanto (2008), menunjukkan bahwa terapi bermain merupakan terapi yang efektif untuk menghilangkan kecemasan anak yang sedang sakit. Karena pada saat dirawat di rumah sakit, anak akan mengalami berbagai perasaan yang sangat tidak menyenangkan seperti cemas, takut, dan sakit. Berdasarkan hal tersebut, dengan melakukan permainan maka akan mengurangi dampak hospitalisasi yang dialami anak, karena dengan melakukan permainan maka anak akan dapat mengalihkan rasa sakitnya pada permainan dan relaksasi melalui kesenangannya melakukan permainan.
Hasil observasi selama penelitian responden yang mengalami kecemasan ditandai dengan beberapa hal, diantaranya cemas, mudah tersinggung, gelisah, merasa tegang, lesu, tidak dapat istirahat tenang, takut pada gelap, pada orang asing, ditinggal sendiri, sukar masuk tidur, terbangun malam hari, tidur tidak nyenyak, bangun dengan lesu, sukar kosentrasi, daya ingat menurun, daya ingat buruk, mudah lupa, hilangnya minat, berkurangnya kesenagan pada hobi, sedih, bangun dini hari, suara tidak stabil, muka merah, pucat merasa lemas, sulit menelan muntah, mulut kering, mudah berkeringat.

Hal ini sesuai dengan pendapat Siti Sundari (2004) kecemasan pada anak ditandai dengan gejala yang bersifat fisik diantaranya adalah jari tangan dingin, detak jantung makin cepat, berkeringat dingin, kepala pusing, nafsu makan berkurang, tidur tidak nyenyak, dada sesak. Gejala yang bersifat mental adalah ketakutan merasa akan ditimpa bahaya, tidak dapat memusatkan perhatian, tidak tenteram, ingin lari dari kenyataan. Perawat dapat mengkaji perasaan dan pikiran anak melalui ekspresi non verbal yang ditunjukkan selama melakukan permainan atau melalui interaksi yang ditunjukan anak. Dengan bermain anak melepaskan ketakutan, kecemasan, mengekspresikan sikap marah dan permusuhan.

\section{Perbedaan Rata-Rata Kecemasan Pada Anak Sebelum Dan Setelah Dilakukan Terapi Bermain.}

Hasil penelitian ini menunjukan ratarata perbedaan kecemasan pada anak sebelum dan setelah dilakukan terapi bermain bercerita adalah 6.33. hasil uji statistik menunjukan bahwa nilai $p$ value $=0,001$, artinya ada perbedaan tingkat kecemasan sebelum dan sesudah terapi bermain bercerita. Keadaan ini menunjukan semua responden mengalami penurunan kecemasan setelah dilakukan tindakan terapi bermain bercerita. 
Penelitian ini sejalan dengan penelitian yang dilakuan oleh Inggrith dkk (2015) didapatkan Ada pengaruh terapi bermain puzzle dan bercerita terhadap kecemasan anak usia prasekolah selama hospitalisasi, skor kecemasan anak sebelum dan sesudah pemberian terapi bermain puzzle dan terapi bercerita. Pada kelompok terapi bermain puzzle didapatkan rata-rata sebelum penerapan 34,71 dan sesudahnya 28,71 dan pada kelompok terapi bercerita didapatkan ratarata sebelum penerapan 37,71 dan sesudahnya 31,12 .

Penelitian ini sejalan dengan penelitian yang dilakuan oleh Lenny Irmawaty (2013) didapatkan ada pengaruh pemberian story telling terhadap tingkat kecemasan akibat hospitalisasi pada anak usia prasekolah di RSUD Kota Bekasi 2013, sebelum dilakukannya story telling sebagian besar anak 56.4\% (22 responden) berada pada tingkat kecemasan sedang. Setelah diberikannya story telling sebagian besar anak 53.8\% (21 responden) berada pada tingkat kecemasan ringan.

Hasil penelitian ini juga sejalan dengan pendapat Supartini (2012) yang menyatakan bermain memungkinkan anak terlepas dari ketegangan dan stres yang dialami anak selama hospitalisasi. Terapi bermain ini juga merupakan salah satu cara

\section{DAFTAR RUJUKAN}

Apriliawati, A. 2011. Pengaruh biblioterapi terhadap tingkat kecemasan anak usia sekolah yang menjalani hospitalisasi di Rumah Sakit Islam Jakarta. Thesis. Depok: Universitas Indonesia.

Gunarsa, dkk . 2012. Keperawatan Maternitas. Jakarta : EGC

Jovan.2007.

Hospitalisasi. http://jovandc.multiply.com. Diakses tanggal 12 September 2016

Lenny Irmawaty. 2013. Pengaruh Pemberian Story Telling Terhadap Tingkat Kecemasan Akibat Hospitalisasi Pada Anak Usia Prasekolah di RSUD Kota Bekasi. Diakses tanggal 12 September 2016

Nursalam,dkk. 2005. Asuhan Keperawatan Bayi dan Anak .Jakarta : Salemba Medika untuk mengalihkan perhatian anak, sehingga anak akan suka pada permainan itu dan faktor-faktor penyebab kecemasaan akan dilupakan. Dalam aktivitas ini anak diajari teknik mengatasi kecemasan sebagai mekanisme koping, misalnya teknik distraksi atau mengalihkan perhatian anak pada aktivitas yang disukainya (Wong, 2001).

Terapi bermain adalah media komunikasi antara anak dan orang lain, termasuk dengan perawat atau petugas kesehatan dirumah sakit (Supartini, 2004). Perawat dapat mengkaji perasaan dan pikiran anak melalui ekspresi non verbal yang ditunjukan selama melakukan permainan atau melalui interaksi yang ditunjukan anak dengan orang tua atau kelompok bermainnya.

\section{KESIMPULAN}

Rata-rata tingkat kecemasan pada anak sebelum dilakukan tindakan terapi bermain bercerita 28.00 dengan kategori kecemasan berat. Rata-rata tingkat kecemasan pada anak setelah dilakukan tindakan terapi bermain bercerita 21.77 dengan kategori kecemasan sedang. Ada perbedaan tingkat kecemasan sebelum dan sesudah dan setelah dilakukan terapi bermain bercerita.

Nursalam. 2008. Asuhan Keperawatan Bayi Dan Anak. Jakarta. Salemba Medika.

Setiawan dkk. 2014. Keperawatan anak \& tumbuh kembang (pengkajian dan pengukuran). Yogyakarta: Nuha Medika.

Sudarmadji, dkk. 2010. Teknik Bercerita. Yogyakarta: PT Kurnia Kalam Semesta.

Supartini, Y. 2012. Konsep dasar keperawaatan anak. Jakarta: EGC.

Survei Kesehatan Nasional (SUSENAS). 2010. Jumlah anak usia prasekolah di indonesia. Diakses pada 11 November 2016

Widjajanto, Nugroho. 2008. Sistem Informasi Akuntiansi. Jakarta: Erlangga, PT Gelora Aksara Pratama.

Wong, D, I. 2001. Buku Ajar Pediatrik. Jakarta. EGC

Wong., \& Donna L. 2003. Pedoman Klinis Keperawatan Pediatrik. Jakarta: EGC. 